\title{
Fabrikazio gehigarria ezinbesteko teknologia osasunean eta industrian: Euskadi eta Katalunia
}

\author{
(Additive Manufacturing as an essential technology in health and \\ industry: Basque Country and Catalonia )
}

\author{
Aitor Tejo-Otero ${ }^{* 1}$, Felip Fenollosa-Artés ${ }^{1,2}$, Irene Buj-Corral ${ }^{2}$ \\ ${ }^{1}$ CIM UPC, Bartzelona \\ ${ }^{2}$ TECNOFAB, Ingeniaritza Departamentua, ETSEIB, UPC, Bartzelona
}

LABURPENA: Azken urteetan, fabrikazio gehigarria (FG) oso azkar garatu da hainbat sektoretan: osasuna, automobilgintza, aeronautika, etab. Aipatutako lehen sektorean, aplikazio anitzetan erabili da: prototipo eta gida kirurgikoak, scaffoldsak, inplanteak. Hobekuntza horiek gaixotasun berriei hobeto aurre egitea ahalbidetuko dute. Industriari dagokionez, fabrikazio gehigarriak aukera ematen die industria-enpresei produktuak prozesu berri ordezko batzuen bidez fabrikatzeko (produktu eta tresna arinagoak, pertsonalizatuak, etab.), hala nola automobilgintzan edo aeronautikan. Gainera, lehen pieza horien fabrikazio-prozesuaren denbora murrizten da. Artikulu honetan, bi eskualdek (Euskal Autonomia Erkidegoa eta Katalunia), medikuntza eta industria arloetan, fabrikazio gehigarriari lotutako aktibitatea berrikusi egingo da. Osasun-aplikazioei dagokienez, bai Euskadin, bai Katalunian, FGak eragin ekonomiko bera dauka bietan; industriari dagokionez, ordea, Euskadiko ekonomian eragin handiagoa dauka Kataluniarekin alderatuta.

HITZ GAKOAK: fabrikazio gehigarria, osasuna, industria, Euskadi, Katalunia.

\begin{abstract}
During the last years, Additive Manufacturing (AM) has rapidly developed in several sectors: health, automotive, aeronautics, etc. In the first sector mentioned, it has been applied in different applications: manufacturing surgical planning prototypes and guides, the use of scaffolds $3 D$ printed, implants, etc. These improvements in the medical field will allow to have more tools to deal with new diseases, and consequently, the life expectancy will be higher. Regarding the industry, $3 D$ printing allows the industrial companies to manufacture better products (lightweight, personalised, etc) in automation or aeronautics, for example. Additionally, there is a decrease in the process time. In present study, two different regions have been reviewed (Basque Country and Catalonia) in the medical and industrial sectors. It has been seen that in both areas AM applied to health applications has more or less the same impact in their systems. However, in terms of the industry, the Basque industry has bigger impact in the economy of the Basque Country.
\end{abstract}

KEYWORDS: Additive manufacturing, health, industry, Basque Country, Catalonia.

\footnotetext{
* Harremanetan jartzeko / Corresponding author: Aitor Tejo-Otero. CIM UPC, Llores i Artigas kalea, 12 (08028 Bartzelona). atejo@cimupc.org - https://orcid.org/0000-0003-2693-3696.

Nola aipatu / How to cite: Tejo-Otero, Aitor; Fenollosa-Artés, Felip; Buj-Corral, Irene (2020). «Fabrikazio gehigarria ezinbesteko teknologia osasunean eta industrian: Euskadi eta Katalunia»; Ekaia, 38, 2020, 315-326. (https://doi.org/10.1387/ekaia.21640).

Jasoa: 08 apirila , 2020; Onartua: 18 maiatza , 2020

ISSN 0214-9001 - eISSN 2444-3255 / (c) 2020 UPV/EHU
} 


\section{SARRERA}

Fabrikazio gehigarria (Additive Manufacturing izenez ezagutzen da nazioartean: AM) piezak eta produktuak ekoizteko eredua da. Arlo horren lehenengo urratsak 70eko hamarkadan eman baziren ere, garapenik nabarmena 2009. urtera arte ez zen gertatu: FDM (Fused Deposition Modelling) izeneko patentea amaitu zenean, hain zuzen ere. Gertaera horrek 3D inprimagailuen prezioen jaitsiera ahalbidetu zuen, eta eskuragarriago egin ziren ordenagailu horiek kontsumitzaile ugariren artean.

Fabrikazio gehigarriaren prozesuak honako pausoak ditu (1. irudia):

1. Produktuaren edo piezaren ideia.

2. CAD (Computed Aided Design) modeloa diseinatzea.

3. Modeloa STL (Standard Triangle Language) fitxategira bihurtzea.

4. STL fitxategia Cura programan edo bestelakoan sartu eta $\mathrm{G}$ kodea sortzea.

5. G kodea 3D inprimagailu batera bidali eta inprimaketa hastea.

6. Produktuaren postprozesua.

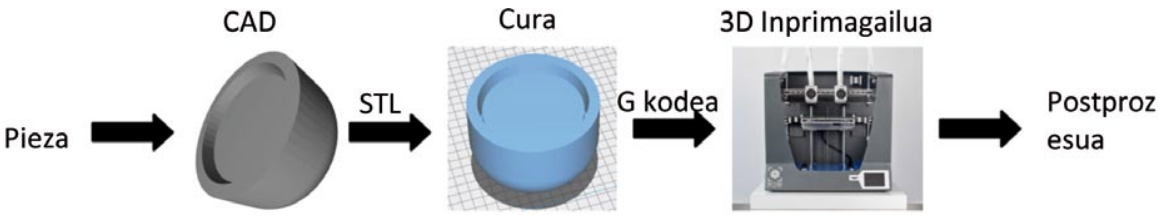

1. irudia. Fabrikazio gehigarriaren prozesua.

Fabrikazio gehigarriaren teknologia-prozesuei dagokienez, hainbat mota daude [1], eta bakoitzak bere aplikazio-eremua dauka; izan ere, ez daitezke material mota ezberdin guztiak teknika guztiekin erabil. Ezagunenak, eta industria- eta osasun-arloetan gehien erabiltzen direnak, hauek dira, ISO/ASTM 2900:2017 terminologia erabilita [1]:

— «VAT Polimerizazioa» (Stereolithography izenez ezagutzen da nazioartean: SLA): erretxin fotosentikor bat UV (laserra) argi-izpi batekin polimerizatzen da. Materiala likido-egoeran dago.

- «Material-estrusioa»: kostu baxuko prototipoak egiteko teknologia da; horretan, polimero bat bere trantsiziozko tenperaturatik gora berotzen da, eta, ilehodi batetik pasatu ostean, ohe baten gainean aplikatzen da, eta berriz solidotzen da. Oro har, erabiltzen den materiala harizko bobina batean dago.

- «Material-estrusioa» (Direct Ink Writing izenez ere ezagutzen da: DIW) deitutako prozesua estrusioan oinarritutako fabrikazio gehiga- 
rrian oinarritzen da. DIWn, fase likidoan dagoen 'tinta' inprimatzen da fluxua kontrolatuta. Mota ugaritako materialak erabil daitezke: bai plastikoak (hidrogelak kontuan hartuta), bai metalak, bai zeramikak.

- «Powder Bed Fusion» (SLM siglaz ezagutzen da nazioartean) prozesuak potentzia handiko laser bat erabiltzen du materialen partikulak urtzeko. Normalean, hauts metalikoa erabiltzen da.

— «Powder Bed Fusion» (SLS siglaz ezagutzen da nazioartean) prozesuak plastiko- edo zeramika-hautsaren materiala urtzen du laser baten bidez. Teknologia honek, FDM prozesua baino garestiagoa izan arren, pieza funtzionalak eta kalitatekoak ekoizten ditu. Baina ezin daitezke erabil FDMan erabiltzen diren material guztiak; izan ere, materialek hauts-formatu estandarizatu batean behar dute egon, eta ezaugarri termiko zehatz batzuk izan behar dituzte, hala nola urtzetrantsizio estua.

- Injekzioak (material jetting) erretxina fotorreaktiboa erabiltzen du piezak ekoizteko.

Artikulu honen helburua fabrikazio gehigarriak osasunean eta industrian dituen eraginak azaltzea da, bai Euskal Autonomia Erkidegoan (EAE), bai Katalunian. Lehenik, EAEko eta Kataluniako fabrikazio gehigarriaren sektoreko analisia egingo da. Bigarrenik, fabrikazio gehigarriaren bidez osasun- eta industria-sektoreetan egin daitezkeen jarduerak aurkeztuko dira. Eta, azkenik, bi adibideen arteko berdintasunak eta ezberdintasunak eztabaidatuko dira.

\section{FABRIKAZIOA GEHIGARRIAREN ANALISIA}

Euskal Autonomia Erkidegoko eta Kataluniako eskualdeak Hego Europako alde garatuak dira fabrikazio gehigarriaren sektorean: bai unibertsitateetan edo zentro teknologikoetan, bai enpresetan (besteak beste, industrian, osasunean, etab.).

\subsection{Euskal Autonomia Erkidegoa}

Urteak joan ahala, Euskal Autonomia Erkidegoa beti nabarmendu izan da bere ingeniaritza-arloagatik; izan ere, industriako lehenengo urratsak siderurgian egin ziren. Gero, ontzigintzak hartu zuen garrantzirik handiena, eta, azken hamarkadetan, honako arloek: automobilgintzak, ehungintzak eta papergintzak. Egun, ordea, fabrikazio gehigarria agertu da merkatura fabrikazio-teknologia alternatibo gisa, eta badirudi gurekin egongo dela denboraldi luze batean. Hori dela eta, ez da harritzekoa hainbat lantegik, zentro teknologikok eta abarrek teknologia hauetan inbertitu eta sakondu izana. Irudian (2. irudia), Euskadin FGa erabiltzen duten enpresak/zentroak 
agertzen dira, beste askoren artean. Gainera, Espainiako fabrikazio-elkartearen egoitza (ADDIMAT) EAEn dago.

3D

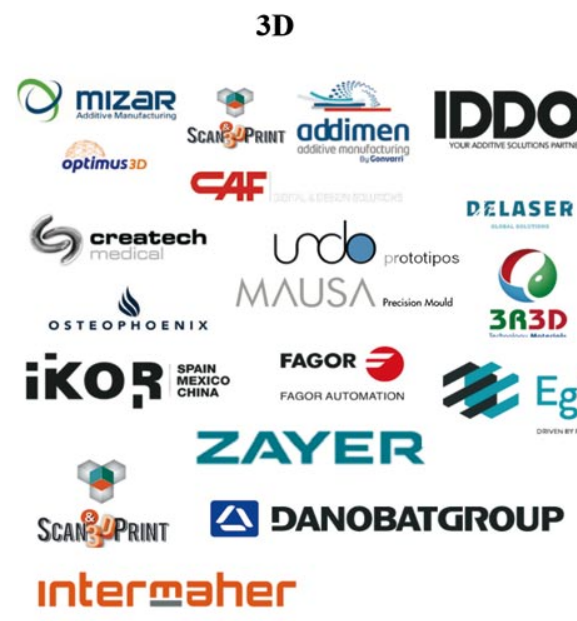

Hezkuntza

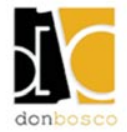

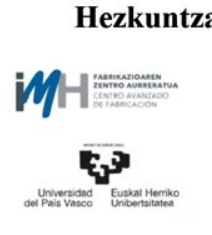

Ospitaleak

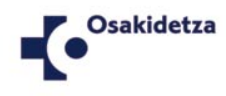

(n)
Banatzaileak

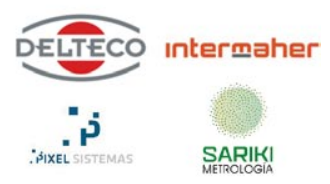

Zentro Teknologikoak

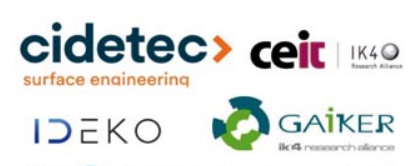

IK4OLORTEK tecnalia)

TKnika IKLO IEKIKER

$Y$ bti

2. irudia. Euskadiko Fabrikazio Gehigarriaren taldea.

Fabrikazio gehigarria ez dago bakarrik industrian edo osasunean, baita beste arlo batzuetan ere. Adibidez, zentro teknologiko askotan, fabrikazio gehigarria erabiltzen da ikerketa egiteko. Era berean, Euskadin finkatuta dauden hiru unibertsitateek fabrikazio gehigarria irakasten dute beren ingeniaritza-eskoletan. Horrela, haietako ikasleak murgil daitezke mundu horretan. Adibidez, badira bost urte Euskal Herriko Unibertsitateak (UPV/ EHU) Fabrikazio Aeronautiko Aurreratuko Zentroa (CFAA) sortu zuela. Beste aldetik, enpresa handi askoren presentzia nabarmendu beharra dago, hala nola CAF (Construcciones y Auxiliar de Ferrocarriles), edo lantegi txiki batzuk ere bai: esate baterako, Optimus 3D.

\subsection{Katalunia}

Kataluniaren pausoak Euskal Autonomia Erkidegoarenak bezalakoak izan ziren, hartan ere garapen teknologikoa izan baitzen. Hala ere, Katalunian enpresa handiagoen presentzia dago, batez ere Bartzelonako hirian; 
izan ere, gune estrategikotzat jotzen da Mediterraneo eskualdean. Irudian (3. irudia), Katalunian FGa erabiltzen duten enpresak/zentroak agertzen dira, beste askoren artean.

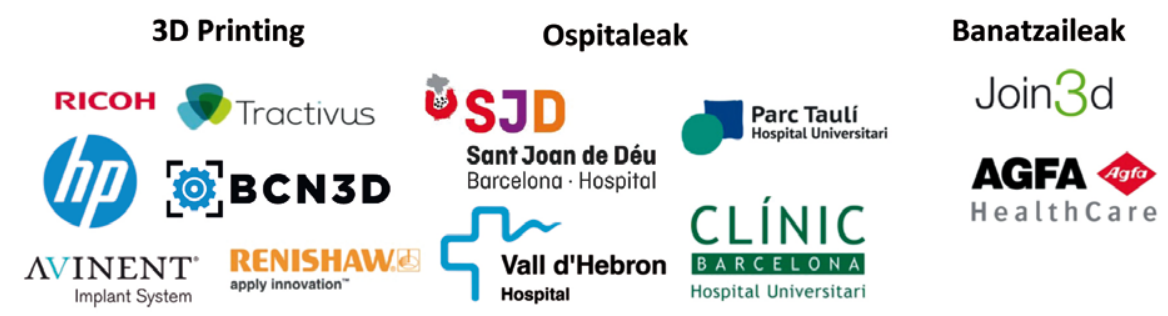

\section{AsorCAL' $\Lambda \mid M$ solutions}

\section{boloberry ELISAVA}

\section{Hezkuntza Zentroak \\ UNIVERSITAT POLITÈCNICA DE CATALUNYA BARCELONATECH \\ at althaia}

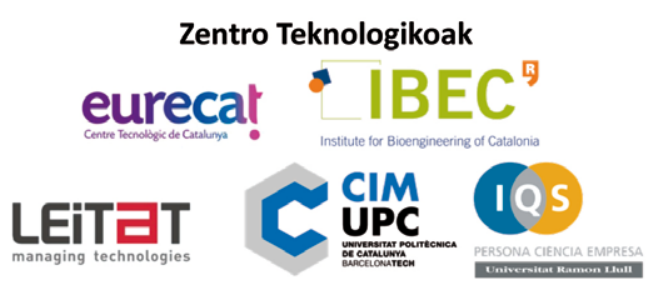

Zentro Teknologikoak

3. irudia. Kataluniako Fabrikazio Gehigarriaren taldea

Euskadin gertatzen den bezala, Katalunian fabrikazio gehigarria ez dago bakarrik industrian edo osasunean, baita beste arlo batzuetan ere. Adibidez, zentro teknologiko askotan, fabrikazio gehigarria erabiltzen da ikerketak egiteko, hala nola CIM UPC, Eurecat edo Leitat. Era berean, Katalunian finkatuta dagoen unibertsitate batek (UPC: Kataluniako Unibertsitate Politeknikoa) fabrikazio gehigarria irakasten du bere ingeniaritza-eskoletan, eta eskola horretako ikasleak mundu honetan murgil daitezke. Beste aldetik, enpresa handi askoren presentzia nabarmendu beharra dago: esate baterako, HP, Ricoh edo Renishaw; edo lantegi txiki batzuk ere bai: adibidez, Bcn3D Technologies.

\section{OSASUNA}

Gaur egun, fabrikazio gehigarria osasun-sektoreko hainbat aplikaziotarako erabiltzen da: gida kirurgikoak, prototipo kirurgikoak, scaffoldsak, inplanteak, etab. Esate baterako, gida kirurgikoak erabiltzen dira zehazta- 
sun handiagoa lortzeko ebakuntzetan. Era berean, prototipo kirurgikoaren xedea medikuen trebetasuna ebakuntzetan hobetzea da; izan ere, medikuek jarduera konplexuak egin behar dituzte ebakuntzan zehar, eta prototipo horiek ebakuntza hobeak egiten laguntzen diete. Horrela, ebakuntzaren denbora murriztea lortzen da, eta, hori dela bitarteko, ager daitezkeen zailtasunak murriztea. Bestalde, scaffolds deiturikoak ehun-ingeniaritzan erabiltzen dira, eta zelulek erabiltzen dituzte, aldi baterako egitura bezala: bertan hazi, eta, gerora, gorputzeko ataletara txertatzen dira. Modu horretan, ehunen birsorkuntza lortzen da. Teknika hori inplante mota batzuekin ere erabiltzen da, hala nola belaunekoa edo aldakakoa.

Baina, zertarako erabiliko da fabrikazio gehigarria urteak joan ahala? (Begiratu 1. taula).

1. taula. Fabrikazio gehigarriaren erabilerak osasunean epe ertainera eta luzera.

\begin{tabular}{c|c}
\hline Epe ertainera (5 urte) & Epe luzera (10 urte) \\
\hline Sendagai pertsonalizatuak inprimatzea & $\begin{array}{c}\text { Neurrira egindako betaurrekoak eskaneatu } \\
\text { eta handik ordu batera 3D inprimagailu } \\
\text { baten bidez betaurrekoak inprimatzea }\end{array}$ \\
\hline Ehun eta odol hodien inprimaketa & Organo eta ehun konplexuen inprimaketa \\
\hline $\begin{array}{c}\text { 3D inprimagailuak ospitale eta farmazia } \\
\text { guztietan }\end{array}$ & GC-MS \\
\hline
\end{tabular}

\subsection{Euskal Autonomia Erkidegoa}

\subsubsection{Gida Kirurgikoak}

Adibidez, UPV/EHUk eta BioCruces Osasun Ikerketako Institutuak masailezurrerako gida kirurgikoak ekoitzi zituzten [2]. Horretarako, erretxin fotosentikor biobateragarria erabili zen, giza gorputzarekiko kontaktuan egongo baita.

\subsubsection{Prototipo Kirurgikoak}

Prototipo kirurgikoei dagokienez, haien erabilera ugaritu egin da aske urteotan. Esate baterako, Zabaleta eta besteren [3] ikerketan, azken urtean izandako esperientzien berri ematen dute autoreek. Horretarako, Bertan, gaixotasun ezberdinetarako prototipoak ekoitzi ziren: biriketako transplantea, bularreko tumoreak, etab. Kasu guztietan ez zen 3D modeloa erabil behar izan; DICOM (Digital Imaging and Communication On Medicine izenez ezagutzen da nazioartean) irudiekin nahikoa zelako. Baina prototipo 
horiek erabiltzea onuragarria dela adierazten da artikuluan. Prototipoak ekoizteko, hiru 3D inprimagailu erabili ziren: SLA, Formlabs Form 2 inprimagailu erabilita; FDMa, Stratasys Fortus 450 inprimagailua erabilita; eta azkenik, material jetting Stratasys J750 erabilita.

\subsubsection{Scaffolds-ak}

Sabada Larraona eta besteren [4] ikerketan, adierazi zen egoera solidoan propietate onak dituzten poliaktida/bario sulfatozko sistema konposatuak 3D bidez inprima daitezkeela. Material konposatu horiek ehuningeniaritzan erabiltzen dira gehienbat, haien propietateak bikainak dira eta. Gainera, erabili den 3D inprimagailua bioploter bat da; hau da, FDM teknologian oinarrituta dago, baina ore formako materialekin lan egiten du.

\subsubsection{Inplanteak}

Mizar Additive Manufacturing lantegiak inplante pertsonalizatuak ekoizten ditu, gaixoaren araberakoak; izan ere, gaixo bakoitzak ezaugarri ezberdinak ditu. Gainera, Osteophoenix enpresak garezurreko inplanteak ekoizten ditu traumek, tumoreek eta abarrek eragindako osasun-arazoak. Hortzetako inplanteei dagokienez, probak egiten ari dira; hala ere, oraindik betiko teknologiak erabiltzen dira.

\subsection{Katalunia}

\subsubsection{Gida Kirurgikoak}

De Vez eta besteren [5] ikerketaren helburua errinoplastian pazienteekiko espezifikoa zen eredua sartzea zen, inprimatutako gida kirurgikoa aurkeztuta eta banakako modu batean egokituta. Gida kirurgiko horiek ebakuntzaren denbora murriztu zuten, prototipo kirurgikoek bezala. Izan ere, osteotomian pauso bat egiten da, asko egin ordez.

\subsubsection{Prototipo Kirurgikoak}

Aplikazio honetan, bi zentro nabarmendu ziren beste guztien gainetik: CIM UPC eta San Juan de Dios Ospitalea. Erreferenteak dira Katalunian, baita Espainiako Estatuan ere. Zenbait artikulu argitaratu dituzte gai honen inguruan [6-10]. Halaber, hainbat teknika erabili dituzte prototipoak egiteko: SLSa, injekzioa (material jetting) eta FDMa; azken hau, moulding teknika baliatuz, zeinean PLA molde bat ekoizten den organoaren negatiboarekin (4. irudia). 


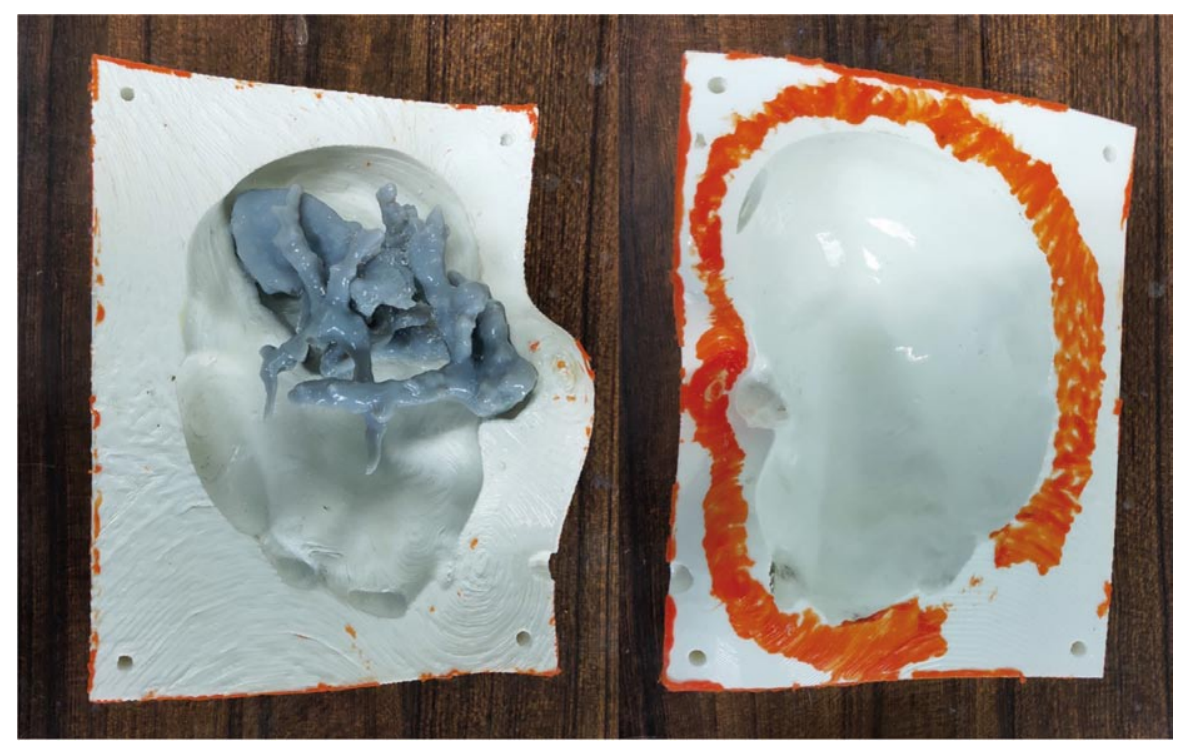

4. irudia. Moulding teknika erabilita ekoizten diren moldeak prototipo kirurgikoak egiteko.

Hala ere, aplikazio honetan, garrantzitsuena falta da oraindik: organoen eta materialen arteko lotura lortzea, hau da, organoetako propietateak kopiatzeko materialak aurkitzea. Normalean, material gogorrak erabili dira, eta horiek ezin izan dute organoen portaera imitatu. Horregatik, azken urteotan, CIM UPCk eta IQSk organoak imitatzeko materialak ekoizten dihardute: bai hidrogelak, bai silikonak.

\subsubsection{Scaffoldsak}

Polonio-Alcalá et al.-ek $[11,12]$, beren ikerketetan, PLAz eginiko scaffoldseko hainbat diseinu inprimatu zituzten FFFko 3D inprimagailu batekin (BCN3D Technologies, Barcelona, Spain). Behin diseinuak inprimatuta, MDA-MB-231 bularreko kartzinomaren zelulen negatiboak landu ziren scaffoldsetan, eta zelulen ugaritze-saiakuntza egin zen. Datuen arabera, porotsuak ziren aukerarik erabilgarriena zelulak hazteko eta ugaltzeko. Horrela, ikusi zen horrelako teknikak erabil daitezkeela minbizia ikertzeko lanak egiteko.

\subsubsection{Inplanteak}

UPCeko unibertsitatean hainbat ikerketa egin ziren aplikazio honen inguruan. Esate baterako, octet-truss 3D egiturak inprimatzea onuragarria izan daiteke ehun-ingeniaritzan erabiltzeko, edo inplanteetan [13,14]. 


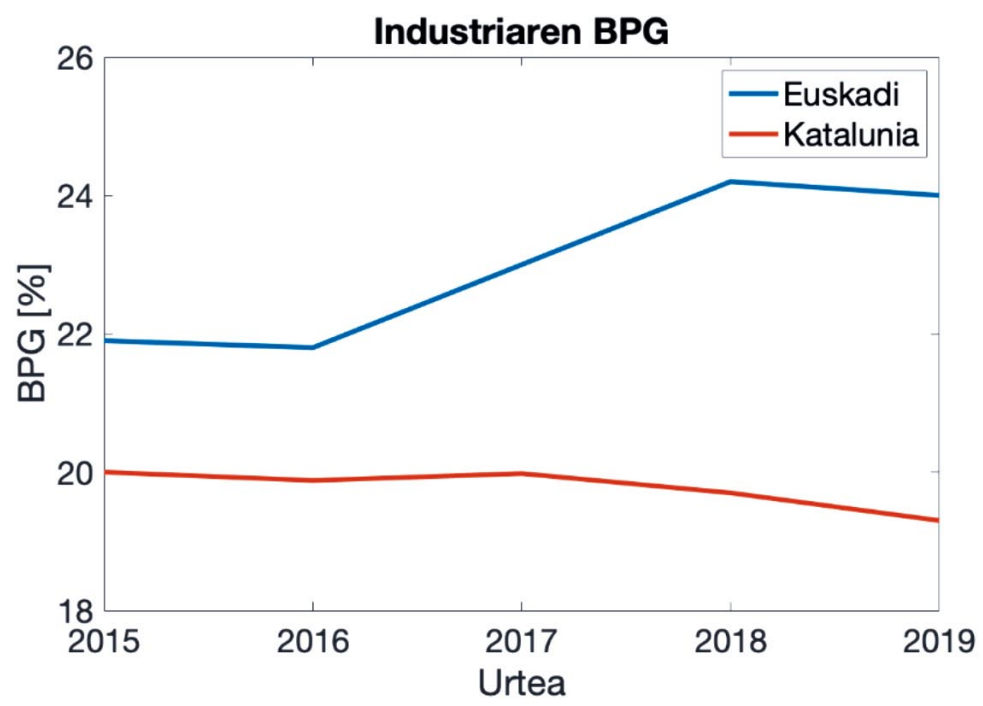

5. irudia. Industriaren BPGa Euskadiko eta Kataluniako ekonomie$\tan$.

\section{INDUSTRIA}

Gaur egun, industriak garrantzi handia dauka mendebaldeko eskualdeetan; izan ere, horietan, hura garatu da gehien azken mendeetan zehar. Industrian, sektore ugaritan erabiltzen da fabrikazio gehigarria, hala nola automobilgintzan edo aeronautikan. Aurreko mendeetan, sektore horietako piezak mekanizazioz egiten ziren, eta material asko xahutzen zen.

\subsection{Euskal Autonomia Erkidegoa}

Euskal Autonomia Erkidegoko industriak inpaktu handia dauka EAEko jarduera ekonomian; izan ere, Euskadiko barne-produktu gordinaren (BPG) \% 22-24 izan da azken urteotan (5. irudia). Gainera, industrian, 200.000 pertsonak lan egiten dute. Nahiz eta ekonomian garrantzi handia izan, fabrikazio gehigarrian ikusten da industriaren garapena posiblea dela; izan ere, urte batzuetara industria BPGaren \% 25 izatea lortu daiteke, eta Europako beste herrialdeen parera iristea.

Euskadin, industria metalurgikoa nabarmendu da gehienbat, eta, horregatik, gehien ekoizten den materiala metala da. Automobilgintzan, adibidez, Optimus 3D-k tresna pertsonalizatuak diseinatzen eta ekoizten ditu, molderik erabili barik; baita aeronautikan ere. Aeronautikan, ULTEM eta Ti-n erabiltzen dira piezak inprimatzeko. 
Era berean, hainbat zentro teknologiko (IDEKO, Lortek, Leartiker, Tekniker, etab.) ikerketa-lanetan aritzen dira. Adibidez, bai IK4-Lortek-ek bai Tecnalia-k parte hartzen duten ikerketa batean, honako hau adierazi da: Alanbre-arku bidezko fabrikazio gehigarria (Wire-Arc Additive Manufacturing - WAAM - siglaz ezagutzen da nazioartean) teknikak deposizio-tasak eta kalitate altuak eskaintzen dituela. Horregatik, alternatiba ona bihurtzen da tamaina ertaineko piezak ekoizteko fabrikazio gehigarria erabiltzea: esaterako, industria aeronautikoan, egiturazko piezak.

Aeronautikan, halaber, Ruiz-Salas-ek eta bestek [15] Laser Melting Deposition (LMD siglaz ezagutzen da nazioartean) teknologia erabili zuten turbomakina-elementuak konpontzeko. Horrela, hainbat esperimentu dira erreferentzia eta abiapuntu gisa.

\subsection{Katalunia}

Katalunian ere inpaktu handia dauka industriak jarduera ekonomian; izan ere, Kataluniako barne-produktu gordinaren (BPG) \% 20 izan da industria azken urteotan (5. irudia); Euskadikoa baino baxuagoa. Gainera, industrian 500.000 pertsonak lan egiten dute. Euskadirekin konparatuta, langile gehiago daude industrian, baina, proportzionalki, gutxiago dira. Bestalde, industriak ekonomian garrantzi handia badu ere, fabrikazio gehigarrian ikusten da industriaren garapena posiblea dela; izan ere, urte batzuetara industria BPGaren \% 25 izatea lortu daiteke, eta Europako beste herrialdeen parera iristea.

Esate baterako, BCN3D Technologies enpresak, CIM UPCen sortu zen spin-off batek, bi buruko 3D inprimagailuak ekoizten ditu. Material anitzeko piezak ekoitz daitezke, eta propietate ezberdinetako materialak batu: (1) bi koloreko materialak erabil daitezke; eta (2) bi material erabil daitezke, hala nola PLA (PolyLactic Acid izenez ezagutzen da nazioartean) edo ABS (Acrylonitrile Butadiene Styrene izenez ezagutzen da nazioartean). Horrela, material anitzezko piezak ekoitz daitezke, eta propietate ezberdinetako materialak batu.

Halaber, badira urte batzuk HPk multi jet fusion deituriko teknologia berri bat asmatu zuela, eta Leitat zentro teknologikoan, teknologia horretako hainbat 3D inprimagailu dituzte industrian erabiltzeko. Multi jet fusion prozesuak hautsaren materiala urtzen du, baina ez du laserra erabiltzen.

Renishaw enpresa metal-fabrikazio gehigarrian aditua da, hau da, SLMa erabiliz, eta industriako hainbat sektoretan dago murgilduta. Alde batetik, automobilgintzan: Renishaw lantegiak neurrira egindako produzitzen ditu (adibidez, hozte-hodiak); gainera, lantegian, metalezko pieza funtzionalak azkar ekoitzi ez ezik, haien errendimendua ere probatu daiteke. 
Eta beste aldetik, aeronautikan: hegazkinen motorrak eta erregai-sistemak fabrikazio gehigarria erabiliz ekoizten dira; hori dela eta, piezak optimizatuta daude: adibidez, pisua murrizten da, eta, horrela, hegazkinak arinagoak dira eta horrek erregaien kontsumoa murrizten lagundu dezake.

\section{ONDORIOAK}

Bukatzeko, orain arte esandako guztia aintzat hartuta, ikus daiteke fabrikazio gehigarria tresna baliagarria dela bai osasunean, bai industrian erabiltzeko. Gainera, Euskadin zein Katalunian fabrikazio gehigarria erabiltzea arrunta bihurtu da, baina ezberdintasunak nabarmenak dira. Esate baterako, Euskadin, gehienbat, unibertsitateek, zentro teknologikoek eta lantegi txikiek erabiltzen dute fabrikazio gehigarria. Katalunian, berriz, enpresa handiek; Bartzelonari esker, bereziki: Europako hegoaldeko leku estrategikoa da teknologiako eta ekonomia handiko enpresentzat.

\section{ESKER ONAK}

Artikulu honetan azaldutako ikerketa, QuiforAM (Exp. COMRDI16-10011) izeneko proiektuaren bidez finantzatu dute, partzialki, Kataluniako gobernuak eta EBko FEDERek.

\section{BIBLIOGRAFIA}

[1] ASTM INTERNATIONAL, ISO. 2017. «INTERNATIONAL STANDARD ISO / ASTM Additive manufacturing - General principles - Requirements for purchased AM parts»., 2016.

[2] Brunso, J., Franco, M., Constantinescu, T., Barbier, L., Santamaría, J. A., Alvarez, J. 2016. «Custom-Machined Miniplates and Bone-Supported Guides for Orthognathic Surgery: A New Surgical Procedure». Journal of Oral and Maxillofacial Surgery, 74, 1061.e1-1061.e12.

[3] Zabaleta, J., Aguinagalde, B., López, I., Laguna, S. M., Mendoza, M., Galardi, A., Matey, L., Larrañaga, A., Baqueriza, G., Izeta, A. 2019. «Creation of a multidisciplinary and multicenter study group for the use of 3D printing in general thoracic surgery: Lessons learned in our first year experience». Medical Devices: Evidence and Research, 12, 143-149.

[4] Larraona, N. S., Fernandez, M., Martin, S., Calafell Martinez, I., Sarasua Oiz, J. R., Muñoz Ugartemendia, J., Zuza Hernández, E. 2017. «Radiopaque Material for 3D Printing Scaffolds»., 454, 451-454.

[5] Herrero Antón de Vez, H., Herrero Jover, J., Silva-Vergara, C. 2018. «Personalized $3 \mathrm{~d}$ printed surgical tool for guiding the chisel during hump re- 
duction in rhinoplasty». Plastic and Reconstructive Surgery - Global Open, 6, 3-6.

[6] Krauel, L., Fenollosa, F., Riaza, L., Pérez, M., Tarrado, X., Morales, A., GomÀ, J., Mora, J. 2016. «Use of 3D Prototypes for Complex Surgical Oncologic Cases». World Journal of Surgery, 40, 889-894.

[7] Muguruza Blanco, A., Krauel, L., Fenollosa Artés, F. 2019. «Development of a patients-specific 3D-printed preoperative planning and training tool, with functionalized internal surfaces, for complex oncologic cases». Rapid Prototyping Journal, 25, 363-377.

[8] Tejo-Otero, A., Buj-Corral, I., Fenollosa-Artés, F. 2020. «3D Printing in Medicine for Preoperative Surgical Planning: A Review». Annals of Biomedical Engineering, 48, 536-555.

[9] Fenollosa, F., Gomà, J. R., Buj-Corral, I., Otero, A. T., Minguella-CANElA, J., UCEDA, R., VAlls, A., Ayats, M. 2019. «Foreseeing new multimaterial FFF-Additive Manufacturing concepts meeting mimicking requirements with living tissues». Procedia Manufacturing, 41, 1063-1070.

[10] Tejo-Otero, A., Lustig-gainza, P., Fenollosa-Artés, F., Valls, A., Krauel, L., BuJ-CorRAL, I. 2020. «3D printed soft surgical planning prototype for a biliary tract rhabdomyosarcoma». Journal of the Mechanical Behavior of Biomedical Materials, 109, 1-11.

[11] Polonio-Alcalá, E., Rabionet, M., Guerra, A. J., Yeste, M., Ciurana, J., Puig, T. 2018. «Screening of additive manufactured scaffolds designs for triple negative breast cancer 3D cell culture and stem-like expansion». International Journal of Molecular Sciences, 19, DOI: 10.3390/ijms 19103148.

[12] Polonio-Alcalá, E., Rabionet, M., Gallardo, X., Angelats, D., CiuRANA, J., Ruiz-Martínez, S., Puig, T. 2019. «PLA electrospun scaffolds for three-dimensional triple-negative breast cancer cell culture». Polymers, 11, DOI: $10.3390 /$ polym1 1050916.

[13] Buj-Corral, I., Bagheri, A., Petit-Rojo, O. 2018. «3D printing of porous scaffolds with controlled porosity and pore size values». Materials, 11, 1-18.

[14] Bagheri, A., Buj-Corral, I., Ferrer, M., Pastor, M. M., Roure, F. 2018. «Determination of the elasticity modulus of 3D printed octet-truss structures for use in porous prosthesis implants». Materials, 11, DOI: 10.3390/ ma11122420.

[15] Ruiz-Salas, E., GonzÁlez-Barrio, H., Calleja-Ochoa, A., Ukar-Arrien, E., LAmikiz-MentXaKA, A. 2018. «Turbo engine components repair methodology by Laser Material deposition». Dyna (Spain), 93, 643-649. 